\title{
Sociology as Public Discourse and Professional Practice: A Critique of Michael Burawoy*
}

\author{
JOHN HoLMwOOD \\ University of Birmingham, Birmingham
}

\begin{abstract}
In this article I discuss Burawoy's (2005) argument for public sociology in the context of the sociologist as both citizen and as social scientist; that is, as simultaneously a member of any 'society' being researched and as researcher claiming validity for the knowledge produced by research. I shall suggest that the relation between citizenship and social science necessarily places a limit on sociological claims to knowledge in terms both of what can be claimed and of the legitimacy of any claims, but that this need not be damaging to sociology as an expert practice producing distinctive and significant forms of knowledge about the social world. Burawoy's claims on behalf of public sociology take their force from the idea of the sociologist as citizen, but they go beyond this limit in a way that would not only undermine the legitimacy of sociology as professional practice, but also, I shall argue, that of public sociology itself. Ultimately, Burawoy argues for a partisan profession that actively promotes human values that he believes to be embodied in the sociological standpoint. In contrast, I shall argue that political neutrality is central to the corporate organization of sociology, not because social inquiry can, or should be, value-neutral, but because corporate political neutrality creates the space for dialogue and is the condition for any sociology to have a voice.
\end{abstract}

Michael Burawoy's 2005 presidential address to the American Sociological Association is a sustained argument for "public sociology." This address and associated promotional activities during his year as President have elicited a wide and largely favorable response, with symposia in Social Problems (51(1), 2004), Social Forces (82(4), 2004), and Critical Sociology (31(3), 2005). The address has also been republished in the British Journal of Sociology (56(2), 2005) with the following issue (56(3), 2005) devoted to a discussion of his call.

The address and related writings on the topic are detailed and I do not have the space to deal with all his claims and qualifications. Like Marx in his critique of Feuerbach, he presents 11 theses, but I shall not deal with all of them. Nor shall I directly address the role of Marxism as a rhetorical trope, although I shall have something to say in passing about the origins in Marxism of his understanding of public sociology. What I shall say will largely be critical, but I do not wish to be misunderstood. I do believe strongly that a public role is central to the sociological undertaking and also that Marxist arguments make a fundamental contribution to the conversation that is sociology, but I will argue that public sociology, and Marxism alike, can only be considered as integral to sociology when the latter is conceived of as

\footnotetext{
*Address correspondence to: John Holmwood, Department of Sociology, University of Birmingham, 32 Pritchatts Road, Birmingham, B15 2TT, United Kingdom. Tel.: +44(0)121 414 7137; Fax: +44(0)121 414 6061; E-mail: j.holmwood@bham.ac.uk. Versions of this article have been given at seminars at the Universities of Sussex and Birmingham. I thank Gurminder K. Bhambra, Jennifer Platt, and William Outhwaite for their helpful comments.
} 
comprising a contested field. Burawoy allows that one of the risks of critical sociology is that it can lapse into dogmatism. I shall argue that his call for public sociologyultimately one that is organized in terms of a foundational critical sociology - is indeed intrinsically dogmatic.

In addressing Burawoy's arguments, I shall concentrate on four underlying themes that organize the different theses that he puts forward. The first is his division of the development of sociology, into three key phases. The second is his conception of the University as a public good. The third is his claim that civil society is the distinctive object domain of sociology, which is to be distinguished from economics, with its standpoint of the market, and from political science, with its standpoint of the state. The fourth theme is his typology of forms of sociology (professional sociology, policy sociology, critical sociology, and public sociology) and the relationships among them. ${ }^{1}$ I shall conclude with a discussion of the public contribution that sociology might make and the problems posed by the special authority of expertise in any relation between sociology and its audiences.

\section{I: SOCIOLOGY IN ITS TIMES}

Burawoy's address comes after considerable soul-searching within U.S. sociology (and elsewhere) about the nature of the discipline, in which commentators have identified inter alia its "impossibility" (Turner and Turner 1990), its "decomposition" (Horowitz 1994), its "identity crisis" (Crane and Small 1992), and its "disintegration" (Stinchcombe 1994), and expressed concern about both the number and the quality of its graduate students (D'Antonio 1992) and the "dilution" of the influence of a disciplinary elite within the ASA (Simpson and Simpson 1994). Burawoy is unsympathetic to such "declinist" views, which he believes reflect a hegemonic professional disquiet about a discipline that is increasingly open to a multiplicity of voices (see also Stanley 2005). Nor is he sympathetic to calls to reintegrate the profession around a new consensus, as promoted by Alexander (1998) and others (e.g., Coleman 1990; Mouzelis 1995; Goldthorpe 2000) in response to a perceived fragmentation of the field. ${ }^{2}$

Notwithstanding, Burawoy's arguments are similar to another declinist discourse on sociology that has lamented its professional narrowness, its apparent evacuation of the public realm, and its retreat into the University (see, e.g., Jacoby 1987; Seidman 1994; Agger 2000). Like these writers, Burawoy offers a three-stage periodization of sociology. ${ }^{3}$ In the earlier period, theorists like Weber, Durkheim, Addams, Gilman, and Du Bois engaged in social inquiry and contributed to public debate in terms both of their critical discourse about society and of the formation of public policy, perhaps

\footnotetext{
${ }^{1}$ Burawoy is not entirely consistent in his use of the term public sociology; sometimes it is used to designate one of the four subtypes, sometimes as a global term that would also include critical sociology and policy sociology, and sometimes to refer to critical sociology and public sociology, taken together, as sociologies with a strongly reflexive dimension. For the most part, I shall be using the term to refer to the latter sense.

${ }^{2}$ It may be noted that the nature of any putative new consensus is different for each theorist promoting it and so, taken together, they appear self-defeating.

${ }^{3}$ This periodization - especially that of the "professional phase" - and its relation to a largely European tradition of social theory applies most directly to the organization of sociology in the United States. The supposed "professional" period of sociology in many other countries is later and, therefore, was a different character and much more open to the critiques of the professional consensus by writers like Gouldner (1970) or Mills (1959). In addition, there are different national traditions of public intellectuals including the denial of a tradition while sustaining one as Collini (2006) has recently argued is the case in Britain.
} 
especially social policy. ${ }^{4}$ Frequently, they did so while moving between different roles. However, the growth of Universities, their specialized divisions of labor, and the professionalization of the discipline led to a narrowing of concerns, a positivistic belief in the production of expert and value-neutral knowledge, a retreat from public debate, and a concern with personal career advancement. As Burawoy describes the consequence of this shift, "if our predecessors set out to change the world we have too often ended up conserving it" (2005:5).

Yet, any high point of professional sociology was short-lived, as, too, was the post-World War II, social and political consensus that was its condition. Just when Parsons (1959) proclaimed that the "end of ideology" had coincided with the "age of [professional] sociology," new social movements arose to disrupt the social and political consensus. ${ }^{5}$ These new social movements were loosely associated as a "new left," and also gave rise to claims for a new politics of knowledge production and new possibilities for sociological knowledge; in particular, for Burawoy, it created new "publics" for sociology and, therefore, new "public sociologies," although he also accepts that there were significant individuals, such as Mills and Riesman, who kept the torch of public sociology alive prior to this.

Although some commentators reflect on these developments as issues of the internal organization of sociology (Turner and Turner 1990; Simpson and Simpson 1994; Stinchcombe 1994), they should also be seen alongside arguments about the wider organization of scientific research and its disciplines. Gibbons and Novotny and their colleagues (Gibbons et al. 1994; Novotny et al. 2001) have argued that there is a general shift where the university is no longer the privileged space for research. This follows from the increased marketability of scientific knowledge with concomitant commercial investment in its production, and government concerns about maintaining effective investment in research and development. They refer to developments across the sciences as a shift from what they call "mode one knowledge production" to a new "mode two knowledge production." The former corresponds to the conventional view of scientific research, based within Universities and organized around the disciplines. In the latter, knowledge production is increasingly transdisciplinary and is part of a "larger process in which discovery, application and use are closely integrated" (1994:46; see also Slaughter and Rhoades 2004). Mode two knowledge will not necessarily supplant mode one knowledge; rather, the two modes will coexist and interact.

They are not uncritical about the consequences of this development, but it is clear that in the social sciences, in contrast to the natural sciences, the emergence of mode

\footnotetext{
${ }^{4}$ Addams and Gilman were both signatories to the founding of the American Sociological Society in 1905 (Burawoy 2005a). Their inclusion in Burawoy's list, along with Du Bois, however, has a wider significance. One of the charges against the "professionalization" of the discipline is that it entailed the narrowing of the canon. One of the concerns of public sociologists is also to challenge that canon (Seidman 1994; Connell 1997). It may be noted that the Society for the Study of Social Problems was founded in 1951 as an "organization committed to social science scholarship in pursuit of a just society" (Karides et al. 2001:113) with its journal Social Problems one of the major journals in sociology established two years later.

${ }^{5}$ It may be noted that the occasion for Parsons's essay was a request by the American Sociological Society that he prepare a paper for a General Session of the 1960 conference on Analysis of the Sociology Profession, a request that had been stimulated by the licensing of psychologists. See Simpson and Simpson (1994). Simpson and Simpson regard the charter of the ASA as an association to promote the discipline, primarily because of the lack of control over employment outside the academy. Ironically, for them, it is precisely the rise within the association of those interested in wider teaching issues (other than those associated with graduate students) and those espousing activist agendas that has pushed the association closer to the form of a professional association, while failing to secure the coherence of purpose necessary to maintain its initial agenda as a disciplinary association.
} 
two knowledge has tended to destabilize relations within and across disciplines. Indeed, there are reasons to suggest that this might be more acute within sociology than in other disciplines. For example, Collins (1994) and Whitley (2000) have argued that disciplines show different degrees of integration with sociology involving more "weakly bounded" groups and a lower coordination of research problems than other disciplines. Economics, for example, shows much higher degrees of integration than sociology, and this engenders a greater claim both to disciplinary coherence and to "scientificity" as understood in terms of the standard criteria associated with mode one knowledge. Crane and Small (1992), for example, use data on co-citations to compare the integration of the different subfields making up the disciplines of sociology and economics. They find that the disciplinary structure of sociology is much more diffuse than economics, lacking a sizable core that incorporates a number of subfields. Moreover, between 1972-1974 and 1987-the two periods of their study - the core in sociology had diminished significantly. ${ }^{6}$ In addition, citations in the subfields also include a significant increase in the number by researchers who are not sociologists.

The transdisciplinarity associated with mode two knowledge in the social sciences is frequently associated with the rise of a generic social science, in the sense that research methodologies are common across the social sciences, rather than specific to particular disciplines (Wallerstein et al. 1996). This has greater impact on disciplines like sociology that were already "loosely coupled." For some writers, the emergence of transdisciplinarity is also associated with globalization and the "decentring" of the nation-state (Taylor 2000). According to Taylor, disciplinary social science - especially, the core trio of economics, politics, and sociology ${ }^{7}$ - is strongly "state-centric." The increasingly global character of transactions and flows requires social inquiry to go beyond the boundaries both of states and of "state embedded" disciplines. This theme is echoed in Beck's (2005) critical comments on Burawoy, where he suggests that the latter fails to address the "methodological nationalism" of the discipline and, by implication, the shrinking of its fields brought about by globalization.

Burawoy refers to these arguments, but only obliquely. For example, the Report of the Gulbenkian Commission into the Restructuring of the Social Sciences (Wallerstein et al. 1996), of which Taylor was one of the co-authors, is described by Burawoy as a "positivist fantasy" for a unified social science (2005:22), but he does

\footnotetext{
${ }^{6}$ Crane and Small, for example, suggest a distinct contrast between sociology in the early 1970s and in 1987: "in the earlier period, sociology had a well-defined core consisting of quantitatively oriented fields, such as social mobility, methodology, demography, and the family. In 1987, the study of social classes and class mobility was no longer linked to methodology and formal theory. Instead, it was linked to Marxian economics, studies of political ideology, and the role of the state, and, more distantly, to European theorizing, in one direction, and the study of revolution, historical sociology, and economics in the other direction. Fields like demography and the study of the family were quite separate fields" (1992:226). For their part, Cappell and Guterbock (1992) identify a bifurcation between "specialities supported by research agencies of the welfare state and specialities that draw inspiration from intellectual, ideological and political opposition movements. This division reinforces the lack of integration between theoretical and applied sociology" (1992:271). Others have used co-authorship across subfields (as defined by section membership in the ASA) to consider the integration of sociology and, on this basis, have argued both for greater coherence than is suggested by Crane and Small and for relative stability over time of that "collaborative network," one that tends to be defined by common methodological skills applied to different specialisms (Moody 2004; see also Ennis 1992).

${ }^{7}$ It is significant that formal representations of disciplines frequently represent economics, political science, sociology, and psychology as the core disciplines, with geography and history outside this core and anthropology usually allied with sociology. Burawoy adopts the standard representation of disciplines. Perhaps unsurprisingly, Taylor is a geographer and others who identify a "postdisciplinary" social science tend to find it in geography (see Sayer 2000).
} 
not address the critique of disciplinary formations that underlies it or any evidence about the disciplinary formation of sociology itself. One of Burawoy's theses, as we shall see, is that sociology is caught in a "scissors movement" between its aspirations and public opinion, but he fails also to see that there is a potential scissors movement in the intellectual division of labor where its object of inquiry is being lost to transdisciplinary research programs, on the one side, and to a unified science of action on the other. ${ }^{8}$

Other developments have also served to radicalize the argument around stateembedded disciplines as a critique not simply of disciplines, but also of the ambition for social science itself. The nation-building that characterized late 19th- and early 20th-century North American and European societies has also been challenged by social movements - for example, by feminism, by postcolonialism, and by environmentalism - that have taken issue with the terms of previously "inclusive" settlements. For Seidman (1994), the project of a science of society, with its pretensions to universal validity, is now to be seen as deeply flawed and its purposes suspect; it has been undermined by the claims of those whose experiences do not fit its categories. Those experiences, or diverse "voices," should be central to any social theory that would embrace democratic pluralism. Given the emphasis on diversity and difference, the appropriate role for the social inquirer is seen as shifting from scientific legislator to that of interpreter (Bauman 1987), or from professional expert to that of partisan (Gouldner 1973). Burawoy also embraces these arguments. His 11 th and final thesis, unsurprisingly given the substance of Marx's 11th thesis that philosophers hitherto have interpreted the world whereas the task is to change it, concerns the sociologist as partisan. At the same time, he argues that this can be consistent with the role of sociologist as expert.

Alan Wolfe (1992), for his part, develops the implication of the decline of "legislative" sociology, suggesting that this marks a shift from strong sociology to strong sociologists. While the middle period was concerned with the development of sociology as a collective endeavor, its most recent period has been more concerned with the development of individual scholarship around the central themes of modernity. In this way, then, public sociology potentially becomes a vehicle for the individualization of sociology. Wolfe does not lament this process, but it is worth noting that whereas the immediate audience for "strong" sociology is the profession itself, strong sociologists are necessarily also oriented to a wider audience since their aim is not to develop research programs but to distinguish their own contributions from others.

Burawoy also recognizes the contributions of strong sociologists to public sociology. However, as we shall see, he is also uneasy about the more general process of "individualization" that is occurring in civil society. In consequence, he is keen to indicate a connection between public sociology and professional sociology against the kind of argument by Wolfe that suggests the decline of the latter and also to distinguish between "traditional public sociology" and "organic public sociology." Wolfe's strong sociologists are practicing the former as, indeed, do Jacoby's "public

\footnotetext{
${ }^{8}$ Others - for example, Runciman (1998) and Fuller (2000) - see the reemergence of sociobiology, in the form of the new evolutionary biology, as also threatening the boundaries between sociology, biology, and psychology, one with which sociologist are ill-equipped to deal, unlike economists, for example, who have tended to emphasize continuity between biology, psychology, and economics (Hirschleifer 1985). The "positivist fantasy" of a unified science does not come from the direction of the transdiciplinary social science proposed by Wallerstein and his colleagues, but from the integration of game theory and evolutionary biology.
} 
intellectuals," while organic public sociologists are sociologists who work "in close connection with a visible, thick, active, local and often counter-public" (2005:7; see also Connell 2000). In this way, Burawoy presents his concerns as both wider and more pluralistic than those of either Jacoby or Wolfe. But can public sociology occupy the space vacated by a diminished professional sociology and are they mutually complementary in the way Burawoy suggests?

\section{II: SOCIOLOGY AS A PUBLIC GOOD}

For those familiar with these debates, the title of Burawoy's address-For Public Sociology - also evokes Alvin Gouldner's essays of "renewal and critique," collected under the title For Sociology, where he argued for a "reflexive sociology." For Gouldner, professional sociology had become part of "everyday social theory," absorbed to the agencies of social control characteristic of welfare capitalism. He linked this argument to the changed role of the University and to a critique of Weber's arguments about "ethical neutrality," which, in his view, had become a mantra of professional sociological practice and were applied outside the context for which they were written (Gouldner 1973a). Weber wrote in circumstances of a highly divided and conflictual public sphere. In this context, the values of ethical neutrality were positive and created a space for debate, but when the public sphere itself has become "de-politicized" those same values are damaging to the very public discourse that Weber sought to establish. While the University in the modern period was initially established as a "cleared space" for public debate, it has now become an "immensely threatened space," threatened by the very professional values that it seems to embody. Professionals encourage dialogue among experts, but not with a wider public; at the same time applied sociologies sold to public agencies or private corporations entail an exchange of services rather than contributions to dialogue.

To some degree, Gouldner had also identified the emergence of "mode two knowledges." While these may have had little impact on the meaning of the natural sciences, they have severely compromised the university itself and its values, values that are necessary to the vitality of sociology itself as a discipline. He writes, "the university's central problem is its failure as a community in which rational discourse about social worlds is possible. This is partly because rational discourse as such ceased to be its dominant value and was superseded by a quest for knowledge products and information products that could be sold or promised for funding, prestige and power - rewards bestowed by the state and the larger society that is most bent upon subverting discourse about itself" (1973b:79). A radically reflexive sociology, according to Gouldner, then, should seek new theoretical communities beyond those compromised within the University. This idea is taken up by Burawoy in his identification of a "new" organic public sociology.

These arguments were also given resonance by Habermas ([1967]1988) in his critique of the "monologic" nature of positivistic knowledge, which he contrasted with the "dialogic" communication characteristic of the "lifeworld." Burawoy adopts Gouldner's mantle, but he also draws on Habermas's distinction between instrumental knowledge and communicative knowledge in his characterization of the different

\footnotetext{
${ }^{9}$ For Wolfe, this is associated with the "rebirth" of classical themes in sociology and marks a shift from journal article sociology to book-length scholarship. It is also "bottom up" sociology, but only in the restricted sense that unlike highly professionalized quantitative sociology, which requires the resources of elite departments, this kind of scholarship can be undertaken in a broader range of institutions. This reinforces the shift away from the elite core described by Simpson and Simpson (1994).
} 
types of sociology. Thus, Burawoy argues that "at least in the United States professional and policy sociologies - the one supplying careers and the other supplying funds - dictate the direction of the discipline. Critical sociology's supply of values and public sociology's supply of influence do not match the power of careers and money. There may be dialogue [between the four sociologies] ..., but the real bonds of symbiosis [are] ... creating a ruling coalition of professional sociology and policy sociology and a subaltern mutuality of critical and public sociology" (2005:18).

This characterization of the current state of the discipline may have had some force when Gouldner wrote, but it is difficult to see that it is as adequate as a description now, for the reasons discussed in the previous section of the article. ${ }^{10}$ The "fragmentation" of sociology may or may not be a bad thing, but there are powerful internal and external forces associated with it and it appears to be real. ${ }^{11}$ For Burawoy, the fragmentation of sociology is to be understood as simply a pejorative name for its multiplicity, but multiplicity, rather than consensus, is the condition for a flourishing sociology. What seems to be attractive about Burawoy's argument is that he proposes a "rapprochement" between different ways of doing sociology. However, I shall suggest that his endorsement of "pluralism" is more apparent than real and, indeed, involves some rather dubious claims about the other forms of sociology alongside public sociology, as well as dubious claims about public sociology itself and, of course, the primary purpose of the address is precisely to bring public sociology but, especially, critical sociology, as we shall see, to the fore.

One immediate issue is that of the nature of the public space in which sociology might make a fundamental contribution. The signs are not propitious. After all, the public sphere is increasing mediated by mass media and commercialized entertainment with the latter influencing reporting, especially in a visual medium like television. Other commentators on Burawoy's arguments, while showing considerable sympathy, tend to stress the difficulties of realizing his hopes. Most of their pessimism surrounds the role of the mass media and the constraining effect of the other institutions in which public sociology is conducted. Stacey (2005), for example, suggests that these constraints convert all critical sociologies into positivistic shadows of themselves as they struggle to be heard in their own terms. ${ }^{12}$

\footnotetext{
${ }^{10}$ Simpson and Simpson (1994) suggest that although the "elite core" has declined in terms of graduate education and recruitment, publication in the core journals- $A J S$ and $A S R$ - has tended to become more concentrated in terms of the position of authors at elite institutions. Karides et al. (2001) compare publication in AJS, ASR, and Social Problems by ASA section specializm showing that women are half as likely to publish in $A S R$ or AJS than in Social Problems and that all three journals favor the "top ten" subfields, varying in the way in which they represent them, with $A S R$ publishing more quantitative articles than $A J S$. Significantly, for Burawoy's argument, however, the top 10 specializms include comparative and historical sociology, sex and gender, and collective behavior and social movements.

${ }^{11}$ Burawoy's position is rather paradoxical. On the one hand, he wishes to deny the fragmentation that the advocates of professional sociology lament. On the other hand, he wishes to undermine the hegemony of professional sociology. His characterization of professional sociology tends to overstate its coherence at the same time as he wishes to restrict its domain and place it under the hegemony of critical sociology. Given that he also argues that professional sociology does produce valid knowledge, it is somewhat odd that he does not discuss the substantive arguments made about the fragmentation of the discipline and their implications for the public sociology he endorses and in particular for the utilization of that valid knowledge in public sociology. For example, he simply dismisses the collections in which contributions by D’Antonio (1992), Crane and Small (1992), Buxton and Turner (1992), and Simpson and Simpson (1994) offer detailed empirical analyses of the disciplinary formation of sociology as the "metaphysical pathos of cognoscenti” (2005a:75).

${ }^{12}$ Burawoy suggests that undergraduate students might also be thought of as a potential public, writing that "we must think of them as carriers of a rich lived experience that we elaborate into a deeper selfunderstanding of the historical and social contexts that have made them who they are" (2005:9). Others tend to see this audience in different terms, but not that different from the way in which Burawoy otherwise characterizes the wider public from which the students are themselves drawn. Thus, Isaac writes, "the
} 
At least part of the problem is the role of mass media in the formation of public opinion and a perceived conflict with sociological opinion. Where Gouldner was responding to claims about the "end of ideology" and a depoliticized public sphere of administered welfare capitalism, the proposed repoliticization - the turning of "social problems" into "political problems," meaning problems for public debate rather than social administration - has had the opposite outcome to that which was expected. The "liberal" establishment of which sociology was seen to be part has collapsed. At least part of the problem for a "state embedded" discipline like sociology is that, unlike economics or political science, it was implicitly attached to a reformist political agenda that, in the United States of America and the United Kingdom at least, has been displaced by a neoliberal agenda. ${ }^{13}$ As Burawoy states, "sociology has moved left and the world has moved right" (2005:6).

Although the statement in itself might not seem to be particularly controversial, the evidence he cites reflects a controversy, namely, the passing of a motion in 2003 by the ASA against the Iraq War. Whereas in 1968, two-thirds of the membership that voted were opposed to the ASA taking a position on the Vietnam War while 54 percent were individually opposed to the war, roughly the same proportion as the rest of the population, in 2003 two-thirds of the membership that voted favored the motion with 75 percent opposed to the war as compared with 75 percent of the population in favor. ${ }^{14}$

Burawoy suggests that the "scissors movement" of sociological and wider public opinion is what propels sociology back into the public arena (2005:20). However, he is rather silent about the fact that when Gouldner made a similar prognosis, the scissors were cutting differently. ${ }^{15}$ In contrast to the latter's expectations, Burawoy's "scissors movement" is associated with an expansion of market solutions to social problems such that, "over the last 25 years earlier gains in economic security and civil rights have been reversed by market expansion with their attendant inequalities and coercive states, violating rights at home and abroad" (2005:7). Implicitly, Burawoy is identifying this as a situation in which policy sociologists should find common cause with public sociologists. Given the shift in public opinion, where once they were

contemporary research university is a complex, byzantine institution governed by the consumer sovereignty of eighteen year olds and their market-driven parents, hardly the site of any emancipatory impulse" (1999: 572).

${ }^{13}$ When Daniel Bell, for example, wrote of the "end of ideology" he stated that "in the Western world ... there is a rough consensus among intellectuals on political issues: the acceptance of a welfare State; the desirability of decentralised power; a system of mixed economy and of political pluralism. In that sense ... the ideological age has ended" (1960:402-03). Burawoy, for his part, suggests that the rough consensus has shifted in favor of market solutions, although I shall suggest that his characterization of the views of economists (and political scientists) is flawed.

${ }^{14}$ Of course, it is not straightforward that opposition to the Vietnam War and opposition to the Iraq War are directly comparable as measures of differences in the attitudes of sociologists and the wider public, and, between the publication of Burawoy's article and this critique, public attitudes in the United States have moved against the war, as they did with the Vietnam War. Some 31 percent of the eligible membership voted. See Footnotes 316 July/August 2003. Simpson and Simpson (1994) argue that the shift from a disciplinary to a professional association is associated with a declining proportion of the membership voting on issues; while pressure for representation of different groups and interests have led to the shift in the character of the association, it also encourages instrumental attitudes to membership.

${ }^{15} \mathrm{As}$ is evident from the introduction to his Coming Crisis, where Gouldner wrote that "social theorists work today within a crumbling social matrix of paralyzed urban centers and battered campuses. Some may put cotton in their ears, but their bodies still feel the shock waves. It is no exaggeration to say that we theorize today within the sound of guns. The old order has the picks of a hundred rebellions thrust into its hide" (1970:vii). Where Gouldner identified an imminent "assault" on state and markets by civil society, Burawoy writes from the opposite perspective where those rebellions must be imagined as having been crushed and urges the dissemination of critical perspectives, "if only as a pebble thrown into the onrushing conservative tide of national politics" (2005a:76). 
part of the establishment, they are now to the left and potentially also left out in the cold. ${ }^{16}$ Their "policy" prescriptions can now be regarded as overlapping strongly with public sociology.

Burawoy does not address the initial radical critique of policy sociology and how it might have contributed to an unsatisfactory status quo. He presents the distinction between instrumental and reflexive knowledge as one that operates to distinguish between policy and public sociology, and one of the consequences is that it is very difficult for him to identify precisely how the economic security and civil rights previously enshrined in the welfare arrangements that he argues have been lost, or are seriously under threat, are to be thought of as positive, since he associates them with a welfare state that is itself assigned to a mere instrumentality. They are not the embodiment of rights or values precisely insofar as they are attributed to what Habermas (1976) calls "steering mechanisms" of the system. Equally important, I will suggest, is that he is unable to provide a space for positive statement of markets"commodification" is an entirely negative term in his lexicon-in any way that might allow debate to be entered with those who understand their operation and consequences differently.

As did Gouldner, Burawoy laments the intrusion of the market into the University evident in the development of mode 2 knowledge and asks rhetorically, "do we have to abandon the idea of the university as a "public good'?" going on to observe that "the interest in a public sociology is, in part, a reaction and a response to the privatization of everything" (2005:7). However, the idea of the University as a public good not only has to have a public that it would serve, it would require to be financially supported by that public, too.

Although Burawoy refers to the increasing gap between sociologists and wider public opinion as evidenced by their respective stances on the Iraq War, he does not reflect on the significance of the very public declaration by the ASA against the war in the light of his argument for the University as a public good. The issue is whether such a declaration is appropriate for a professional association. Burawoy does not identify this as an example of the kind of public activity appropriate for an association in his presidential address, but he does in a related article, where he writes that "instead of basing their resolutions on direct research evidence, sociologists were expressing the value presuppositions that underlie their research programs and their assessment of world events" (2005a:80). ${ }^{17}$ This seems to imply a shift in the normal

\footnotetext{
${ }^{16}$ In fact, a survey carried out by Ladd and Lipset (1975) suggested that academics generally were, at that time, also typically to the left of the American population. The difference is that the population might then have been argued to be moving on the same trajectory.

${ }^{17}$ In the same article he refers to the politicization of sociology, suggesting that it is unaffected by these kinds of public declaration, writing that "if sociology is politicized, it is most often at the hands of politicians and irrespective of its public character. Thus, sociological research but not just sociological research has come under attack in the U.S. Congress, threatening federal programs that support, for example, research in the area of sexual behavior - so essential to the understanding of sexually transmitted diseases"(2005a:76). However, it is worth noting that at the same time as issuing the declaration against the war in Iraq the ASA was also required to take a stance against the "politicization" of the peer-review process, itself a significant part of professional self-regulation. A congressional amendment to the Labor, Health and Human Services and Education LHHS FY 2004 Funding Bill, which sought to remove funding from five National Institutes of Health grants, four of which involved social and behavioral research on health. See Footnotes 317 September/October 2003. The move failed by two votes and was sponsored by "pro-family" lobbies; had it succeeded, it would have undermined the peer-review process. Similar successful interventions by government into the peer-review process have been reported in Australia, where the Federal Minister for Education has vetoed grants recommended by the Australian Research Council in two successive years.
} 
understanding of professional ethics in line with the perspective of critical sociology. ${ }^{18}$ For the former, corporate political neutrality is argued to be integral to professional ethics and to the form of professional self-organization conceived as a public good, a status it derives, in part, from its association with the University system.

\section{III: SOCIOLOGY AS A GUARDIAN OF CIVIL SOCIETY}

Burawoy argues that sociology is identified with "the standpoint of civil society," thereby distinguishing it from economics, to which he attributes the standpoint of the market, and from political science, to which he attributes the standpoint of the state. These standpoints, he suggests, were established at the birth of the social sciences, and while the standpoint of sociology became blurred in the second period when professional objectivity dominated, it has been reproduced once more over the last few decades as civil society has been under threat from "state unilateralism" and "market fundamentalism." Throughout this latter period, Burawoy writes, "civil society has been colonized and coopted by markets and states" (2005:24). Moreover, in its affiliation with civil society, "public sociology represents the interests of humanity - interests in keeping at bay both state despotism and market tyranny" (2005:24). For Burawoy, this involves the recognition that critical sociology "enters as guardian of the discipline and conscience of professional sociology" (2004: 105).

Given that the impetus to domination is associated by Burawoy with the "logics" of states and markets, sociology seems excused from any implication in that domination; apparently its categories are formed in "reaction" to modernity, rather than in the construction of its core and problematic meanings. Although he allows that postcolonial arguments represent new voices in the sociological dialogue, he constructs sociology in such a way that they do not bear on its previous constructions. Burawoy's ninth thesis is the need to "provincialize" American sociology and to recognize the requirements of global social inquiry, but it seems that is not something that to be achieved would require a reconstruction of sociology either in its categories or in the logic of its forms. ${ }^{19} \mathrm{He}$ recognizes that the balance among the four types of sociology might be different in different national contexts, where a strong version of the

\footnotetext{
${ }^{18}$ Some members of the ASA sought to bring an action against the association for a breach of its code on research ethics, which state that "in research, teaching, practice, service, or other situations where sociologists render professional judgments or present their expertise, they accurately and fairly represent their areas and degrees of expertise" (American Sociological Association n.d.). For those bringing the case, the declaration did not reflect competent expertize utilizing the research-based opinion of the association, such as might be the case, for example, when presenting a position, say, on racial discrimination. The Council of the ASA judged the motion not to be appropriate, in that the code of ethics applied to members as individuals and not to the association corporately. As we have seen, its President-elect was directly of the view that the justification in ethics of the declaration against the war was different from that laid down in the ASA Code of Ethics.

${ }^{19}$ His treatment of postcolonialism and feminism are similar. For example, as Joan Acker (2005) has pointed out, one obvious limitation of this definition of the sociological standpoint is that it displaces feminism from the central definition of public sociology. After all, the household and, in particular, its interrelationships with emerging labor markets and the state, were neglected in early contributions to sociology, precisely because the focus was on civil society and the relation between market and state. In the process, gender divisions were rendered "invisible" to the sociological gaze. Acker's observation can also be extended to the treatment of issues of colonialism. in the formation of capitalist modernity. As GhamariTabrizi argues, "the big absent in Burawoy's long list of events in response to which sociology emerged is colonialism. Indeed, colonial encounters were instrumental to the founding binaries of sociology: ie, modern versus traditional, Gesellschaft versus Gemeinschaft, public versus private, etc" (2005:367). Most sociological accounts of modernity of whatever period abstract from how the institutions associated with modernity were produced in colonial encounters. Rather, modernity tends to be treated as an "endogenous" process of transformation associated with Europe (Bhambra 2007).
} 
professional role is less available because of the urgency of local problems. Given the disparity of resources available for research, the ability to define problems is likely to remain centered in the United States, especially if, for understandable reasons, other "provincial" sociologies are likely to remain "state embedded." 20

Equally serious are the issues of the relationships between the disciplines that Burawoy proposes. Political science and economics are part of the University, but while they benefit from its status as a public good, apparently they are its enemies, too. He is quite explicit on this: "I do believe that economics and political science have manufactured the ideological time bombs that have justified the excesses of markets and states, excesses that are destroying the foundations of the public university, that is, their own academic conditions of existence, as well as so much else" (2005:24). They could be "rescued" by following the lead of sociology, but, of course, sociology has also been in the thrall of "instrumental reason" and is only now recognizing the possibility of public sociologies that will lead sociology back to its critical standpoint of civil society and the defense of humanity. Political science and economics have greater public acceptance and credibility than sociology, but, ironically, if Burawoy is correct, that acceptance can only be understood as deriving from the very deformation of the public sphere that his public sociology sets out to repair.

There are reasons to suggest that Burawoy's characterization of economics (and that of political science, too, but I do not have the space to demonstrate it) is inadequate. It is not simply that there are "heterodox" forms of economics, as he allows, but that his representation of the nature of orthodox economics is at odds with other characterizations of the discipline. To be sure, it has a coherent core or, at least a core more coherent than sociology, but recent writers have argued that it is not organized around neoclassical assumptions (Colander 2000) and might anyway be in the process of becoming more pluralistic (Davis 2002). Moreover, Davis (2002), following Morgan and Rutherford (1998) and Goodwin (1998), suggests that the achievement of a coherent core was a consequence of maintaining a stance detached from political engagement in order to secure claims to neutral expertise. Davis does suggest that although economics may lack a "monolithic" ideological presence, it may nonetheless "exercise an undetected ideological presence, behind the backs of individuals, as if by an invisible hand" (2002:151), but this is a rather different construction of the problem of economics as a discipline than the one put forward by Burawoy. ${ }^{21}$

\footnotetext{
${ }^{20}$ In this context, it is worth observing that despite Burawoy's observation of the need to "provincialize" American sociology, his address ends with the need to establish criteria for public sociology where the major practical issues will be addressed via an ASA "task force for the institutionalization of public sociologies" that will consider three key issues: how to recognize and validate that public sociology that already exists; how to introduce incentives for public sociology that is usually slighted in merits and promotions; and how to distinguish good from bad public sociology (2005:25). This is not so much designed to provincialize American sociology as to professionalize public sociology. As Ghamari-Tabrizi argues, "Burawoy rightly identifies the parochialism of American sociology as one of the barriers for the emergence of a global sociology. The problem, however, remains when such a recognition would only have currency if it comes from Burawoy and other influential sociologists of the Global North. Who gets to define it and who practices it is as important as what public sociology is" (2005:367). Similar observations have been made by Connell (1997:2000).

${ }^{21}$ Surveys of the public policy views of economists show considerable variation among economists and cross-nationally (Ricketts and Shoesmith 1992; Mayer 2001). In line with Colander's view about the greater commitment to value-neutrality in economics, these surveys show a concern that the indication of ideological preferences with discernible effects might call into question the standard "scientific" view of the discipline, but they do not demonstrate a marked conservative consensus. While U.K. economists are more to the left than U.S. economists in terms of their willingness to countenance income redistribution and "Keynesian" policy measures (Ricketts and Shoesmith 1992), the picture even of the core of the discipline
} 
Davis argues that the economics described by Colander as no longer neoclassical has become organized in terms of techniques and methods that efface the individual. For him, the problem with economics is less that it promotes a particular ideology, but that it removes economics from making a contribution to normative questions. This opens a rapprochement between economics and sociology, but if this is a positive development as far as interdisciplinary connections between economics and sociology are concerned, it is hardly promoted by Burawoy's representation of their relation in such polemical terms. ${ }^{22}$

Burawoy's view of the "colonization" of civil society by markets and state is derived from Habermas, but his analysis is rather crude. On the one hand, he writes as if the process is potentially uniform across different societies or at least that it carries that risk, but in posing the threat as the colonization of civil society, what is suggested is that some degree of state formation and market provision may be appropriate. Is some market provision and state formation in the "interests of humanity"? Or are the interests of humanity to be served by the reduction of state and economy to civil society? There is only one public sociologist, Marx, who potentially saw the market, as such, as the enemy of humanity and even that was in rather special sociological conditions. $^{23}$ Those conditions included the polarization of classes and the limit posed by the market on state regulation of their operation. Burawoy's critique of markets, and the state in its support of markets, as "antihuman" takes its force from the Marxist analysis of capitalism that underlies it and, as I have suggested, many sociologists, including Marxists such as Wright (1985), would dispute the adequacy of that analysis.

It is worth reminding ourselves that prior to Marx, markets - and the commodification of activities that they produce - were associated by social theorists with human freedoms, as they are today by some of those that Burawoy demonizes. Nor need markets be seen simply as the enemy of the "lifeworld," but also as one of the conditions for the development of a "democratic" lifeworld. ${ }^{24}$ For Durkheim (1992), for example, state regulation was an antidote to the anomie produced by the unregulated expansion of markets, but markets were necessary to the "social individualism"

does not correlate with Burawoy's account even at the height of "new right" political ascendancy in the United States and the United Kingdom.

${ }^{22} \mathrm{~A}$ note of caution should be sounded here, since a more pluralist economics is still one with greater integration across its various subfields. If economics is organized around a series of methods and techniques, these are not directly those associated with the transdisciplinary, generic social science, but those of formal modeling. An alliance between economics and sociology does not seem to derive from this development, which is in any case associated with the fragmentation of sociology. Burawoy offers rather general ideas about the positive nature of interdisciplinary alliances, but the cogency of these ideas depends on the adequacy of his description of sociology itself as a discipline. Like Scott (2005), he suggests that the "new economic sociology" (Smelser and Swedberg 1994) is a subfield of the discipline that opens the way for a positive relation between sociology and economics. For their part, Crane and Small identify clusters where economics specialties and sociology specialties were linked and this was a new development between 1972-1974 and 1987. However, the interchange tended to be one way with 38 percent of the sociology clusters citing references in economics and only 6 percent of the economics cluster citing sociology references (Crane and Small 1992:227).

${ }^{23}$ It is easy to see why Marx regards commodification as problematic, given its association with polarization and exploitation. However, given that most Marxists accept that polarization is not an adequate description of the stratification order, the possibility must exist that the market and commodification can secure positive freedoms, for example, those associated with the choice of occupation and the ability to become something particular and serve the needs of others, especially if welfare arrangements can address contingencies in the operation of markets (Winfield 1988).

${ }^{24}$ The writers of the Scottish Enlightenment, for example, saw a connection between commerce and the "civilization" of social intercourse, including relations between the sexes and "democratic friendship" separated from other obligations of support and patronage. See, for example, Hirschman (1977), Silver (1989), and Becker (1994). 
that he endorsed and the combination of state and market helped to secure a healthy civil society of secondary associations, including those governed by professional ethics. Indeed, while Durkheim was a critic of liberal economics, it was not on the basis of a sociology identified with "civil society," but in terms of its concern with the nature of institutions, which would necessarily include markets and state as well as the family household and the relations among them. Similarly, Polanyi (1944) - who Burawoy cites favorably in other writings - is a critic of the "fiction" of self-regulating markets and its role in public policy debate, but not of markets as such, once they have been understood substantively and polices adopted accordingly.

Durkheim was also emphatic that professional associations did not replace individual egoism by collective egoism, yet radical critiques of the professions have made this charge (Larson 1977; Collins 1990). In line with this critique, professional knowledges are characterized by Burawoy as both "monologic" and "self interested." 25 At the same time, professional monopoly requires the sanction of the state, just as the public University requires a similar endorsement. Yet, it is the very monopolistic form of professional self-organization that encourages critical sociologists to deny the substance of professional claims. Does this not indicate an unacknowledgedthat is, not reflexively aware - convergence of radical sociology and neoliberal views, in the sense that each regards monopoly as a problem from the point of view of a wider public?

\section{IV: SOCIOLOGY AND ITS FORMS}

I have developed this critique of Burawoy's call for "public sociology" so far without addressing directly his typology of forms of sociology and the relations between them. This typology sets public sociology in a wider context and appears to reconcile it with sociology as professional practice, but I shall suggest that it does not really overcome the problems identified earlier. It accentuates them.

Burawoy's third thesis is that "public sociology is part of a broader division of sociological labour that also includes policy" (2005:9). In setting out this division of labor, he draws a typology of sociological knowledges and their audiences. As I have already commented, two kinds of knowledge are distinguished - instrumental knowledge and reflexive knowledge - and two kinds of audience - academic and extra-academic. Professional sociology and policy sociology are drawn along the axis of instrumental knowledge addressing academic and extra-academic audiences, respectively, where the extra-academic audience are clients in the state bureaucracy or private market. Professional sociology, produces knowledge that may be applied to practical policy or organizational problems by policy sociologists. The knowledge claims of professional sociology occur through "puzzle solving" (the term derives from Kuhnian normal science), while policy sociology is "problem solving" (by which he means oriented to social problems). Along the reflexive knowledge axis, there is a similar distinction between public sociologists who address issues and problems in civil society either in terms of public discourses about society, as in "traditional" public sociology, or in terms of countermovements of civil society, as in the case of "organic public sociology." Public sociology serves public debate and is, therefore, argued to be "dialogic" with its external audience, but there is also a domain of "dialogue

\footnotetext{
${ }^{25} \mathrm{He}$ argues, for example, that "professional sociology's concern [is] to develop a monopoly of abstract, specialized knowledge, evaluated by peers" (2005a:74).
} 
about dialogue," that of critical sociology whose audience is academic. This internal dialogue serves to legitimate the claims of public sociology, in the same relation that professional sociology stands to policy sociology.

At the same time, the instrumental knowledge of professional sociology can be put to the service of public sociology as well as policy sociology and its clients. Burawoy writes, "there can be neither policy nor public sociology without a professional sociology that supplies true and tested methods, accumulated bodies of knowledge, orienting questions and conceptual frameworks. Professional sociology is not the enemy of policy and public sociology, but the sine qua non of their existence" (2005:10). If there is no public or policy sociology without professional sociology, the same holds true for critical sociology, but with a twist, "without a professional sociology, there can be no policy or public sociology, but nor can there be critical sociology-for there would be nothing to criticise" (2005:15; my emphasis).

I will leave aside for the moment that what Burawoy proposes to criticize he has also described as consisting in "true and tested" methods and "accumulated bodies of knowledge." He draws on the work of Lakatos (1970) to suggest that professional sociology is made up of research programs that eventually come to degenerate and be transformed when swamped by anomalies and their puzzle-solving moves appear no longer to be innovative. What he also proposes, however, is a form of criticism beyond that implied by the conception of research programs. It is difficult to see what this criticism would be other than criticism of the "hard core" assumptions of research programs, which is precisely to deny research programs their putative role in the professional quadrant.

Burawoy nowhere addresses directly any issues in the application of the concept of a research program to sociology. As argued in the first section of the article, sociology does not appear to display the features associated with the physical sciences, for which Lakatos developed the concept of a research program. As I have argued, and much evidence demonstrates, sociology as a field is much less "tightly coupled" than the physical sciences. The tendency in the latter is for research programs to succeed each other, while sociology, at best, would be characterized by "multiple research programs," where the very use of the term research program serves to suggest that they are relatively well insulated from each other. It is difficult to see how the domain of professional sociology can be characterized by the production of "true and tested methods" and "accumulated bodies of knowledge" if the relevant "tests" and knowledge claims are internal to research programs and there is no agreement across them. In his description of the criteria for knowledge and associated truth claims that apply in the professional quadrant, then, Burawoy is forced back to a more positivistic formulation, where "the knowledge we associate with professional sociology is based on the development of research programs ... [and] ... the focus is on producing theories that correspond to the empirical world" (2005:16). If this were correct, what would be open to criticism would be a selective concern with some part of the empirical world to the neglect of other aspects.

Burawoy also presents his view of the relation between the four quadrants as a "normative vision" of "reciprocal interdependence among our four types - an organic solidarity in which each type of sociology derives energy, meaning and imagination from its connection to others" (2005:15). So far, I have suggested that this "solidarity" involves the annulling of characteristics he wishes to attribute to each quadrant or, at least, I have shown that he modifies the description of processes internal to research programs, by locating the justification of their basic assumptions externally within critical sociology. This is because, even as he describes it, interdependence 
is also a hierarchical relation, where critical sociology holds the dominant position, since "reflexive knowledge interrogates the value premises of society as well as our profession" (2005:11). ${ }^{26}$ Critical sociology is guided by normative foundations that provide the normative vision that binds the reciprocal interdependence among the four types of sociological knowledge.

Burawoy (2005:11) remarks that the scheme bears a "uncanny resemblance" to Parsons's functional scheme. Indeed, he assigns each of his four quadrants to the latter's A-G-I-L scheme, with professional sociology aligned to the adaptive function, policy sociology to the goal attainment function, public sociology to the integrative function, and critical sociology to the latency function. The resemblance is both uncanny and unsettling, given that he fails to address the standard criticisms addressed to a scheme of this sort-namely, that it is a priori and does not derive from an examination of the activities under consideration. Nor does he address the particular application of the scheme to the University and its academic divisions of labor by Parsons and Platt (1973). Although I do not wish to dwell on this latter failure, it is significant precisely because their motivation, in large part, was to address the very "politicization" of the University by the proponents of critical sociology in the 1970s. For them, this had "deflationary" consequences for the University as a public good. Burawoy is now mobilizing critical sociology in defense of a "deflated" public University system, without addressing major arguments that critical sociology has itself played a part in that deflation.

Insofar as the descriptions of the relevant activities are equivalent, Burawoy offers a simple inversion of Parsons and Platt's application of the A-G-I-L scheme. They associate the University with "cognitive rationality," which, as part of the wider cultural system, is assigned to the adaptive function. This provides a further fourfold categorization of the institutionalization of cognitive rationality in the structure of the University (Parsons and Platt 1973:92). ${ }^{27}$ However, the core of cognitive primacy"research and graduate training by and of specialists," or, what in the case of sociology would be Burawoy's domain of professional sociology-is assigned to latency. Unsurprisingly, the position of critical sociology in Burawoy's scheme, then, is occupied by that of professional sociology; it has the superior position in the "cybernetic hierarchy."

In Parsons and Platt's terms, Burawoy is guilty of a conflation of the cultural system with cognitive rationality and, in the process, implicitly assigning the protection of wider cultural values to a particular "interest group," namely, a subset of critical sociologists. The irony of this conflation, from their perspective, is that the A-G-I-L scheme is peculiarly suited to explicate it. For Parsons, the "current ideological controversy" over the idea of value freedom is bound up with the view that

\footnotetext{
${ }^{26}$ In a previous version of the paper, Burawoy had appeared to Stanley (2005:para 2.8) to assign the dominant role to professional sociology, for writing that "rather than looking backwards ... I look forwards to a unity based on diversity - a unity that incorporates a plurality of perspectives. In this vision, professional sociology, in order to safeguard its own enlightened self-interest, must be prevented from colonizing critical and public sociologies. We have to institutionalize these subordinate sociologies within the academy alongside a hegemonic sociology" (2004:1612). In his later version of the article, Burawoy has clarified this ambiguity; it is evident that he intends the statement of professional sociology's hegemony as "description," rather than "prescription." The prescription is now clearly in favor of critical sociology.

${ }^{27}$ They agree with Burawoy that the "training of professional specialists" or policy sociologists should be assigned to the goal attainment function, while contributions by "intellectuals as generalists" to the definition of the situation are assigned to the integrative function, This broadly fits with the role of public sociology in Burawoy's scheme. The training of undergraduates as "generalists" is assigned by Parsons and Platt to the adaptation function.
} 
it is a "derogation of the dignity of culture in general" (Parsons 1978:142). There is a direct parallel, Parsons suggests, with Marx's treatment of alienated labor, "current ideological controversy, then, concerns the alleged alienation of man's cultural heritage by subjecting it to the discipline of cognitive standards, a discipline analogous to the economic discipline of the labor factor. The same ideological controversies involve an idea of the exploitation of cultural standards by pressing them within the mold of this discipline and the alleged suppression of alternative possibilities, notably in moral-political and expressive directions" (1978:142).

Given the association of the A-G-I-L scheme with the process of structural differentiation, Parsons identifies the critique of "value-freedom," and its associated idea of the "corporate political neutrality" of the University, with hostility toward complexity and the advocacy of structural dedifferentiation. Burawoy appears both to affirm structural differentiation in his embrace of the A-G-I-L scheme and, at the same time, lament it in his critique of the dominance of cognitive rationality. Moreover, the way in which he sets sociology against other disciplines and his lack of clarity about the nature of state, economy, and civil society relations and whether the "decolonization" of the lifeworld involves dedifferentiation, suggests serious flaws in his conception of a differentiation of four distinct, but mutually complementary, sociologies. ${ }^{28}$ What he recommends socially-dedifferentiation-seems to be the opposite of what he recommends for sociology-differentiation.

\section{V: CONCLUSION}

Although I do believe that the account offered by Parsons and Platt is superior to that of Burawoy, I do not mean to imply that it is adequate. Each version of the academic division of labor involves a hierarchy among forms of sociology and an implied foundational consensus that secures the places in the hierarchy. Thus, Parsons suggests that professional sociology occupies the pinnacle in the cybernetic hierarchy and this, in turn, is presupposed on the acceptance of a foundational frame of reference that is outside the process of empirical research, but secures it. ${ }^{29}$ Burawoy, for his part, suggests that professional sociology is lower in the hierarchy than critical sociology, which provides the proper critique of its core theoretical assumptions as well as locating that critique in terms of cultural - that is, human values.

Where Parsons merely has to contend with the problem of a foundational consensus in a professional field that shows no signs of it, Burawoy has the harder task of justifying a foundational consensus as the "true underpinning" of values in the "public realm." In each case, the resolution is similarly dogmatic; a consensus is implicitly presupposed by a proper "theoretical" understanding of the respective activities. Disagreement is a deficiency in understanding. In the case of Burawoy, the "dialogic" consensus between the practitioners of public sociology and their publics, that is, the criterion of truth, is always open to critique as "falsely achieved." That

\footnotetext{
${ }^{28} \mathrm{He}$ argues that "we need to bind ourselves to the mast, making our professional, policy, public and critical sociologies mutually accountable" (2005:17), but what is lacking is an account of their mutualitythey are divided across the "instrumental/reflexive" line - that would not also apply to system and lifeworld more generally.

${ }^{29}$ At the bottom of the hierarchy is the "fitting' of theory to operational procedures of research" (1954b: 351). This viewpoint is also found in recent claims that sociology requires a foundational consensus on presuppositions in order to secure it against fragmentation and relativism. See, for example, Alexander (1982) and Mouzelis (1995).
} 
critique is, itself, located within a higher-level dialogue on normative foundations, conducted as an "internal debate" among critical sociologists. At its most profound, it seems that a dialogic public sociology can declare its public - that is, the public from which it seeks to draw its legitimacy, since it is their interests it expresses - not yet ready for dialogue, or in need of creation by the call to dialogue. ${ }^{30}$

If Parsons tends to the reification of professional sociology, Burawoy reifies critical sociology. At the same time, each wishes to defend the University as a public good. For Parsons, that means accepting the doctrine of value freedom and a professional consensus on the conceptual framework in which sociological knowledge is produced. In this way, he suggests, sociological knowledge can share in the public legitimacy accorded to scientific knowledge more generally. For Burawoy, the search for objective knowledge independently of questions of public interest would condemn sociology to irrelevance. Although he argues that the knowledge produced within professional sociology can be utilized to address matters of public relevance, his conception of public sociology invokes an ideal public in criticism of existing publics.

However, as Stephen Turner (2003) has argued, it is precisely because sociology engages with matters of public relevance that its knowledge claims are most likely to be publicly contested and its legitimacy challenged. Indeed, the very process of democratization, to which public sociology is connected, calls into question the mobilization of expertise to settle public debates. Moreover, as Turner argues, the mobilization of that expertise is most problematic in the absence of any settled consensus about the status of knowledge within a field, with the more tightly coupled the field, the greater the public legitimacy of expertise mobilized on its behalf. What is problematic for each position, Burawoy's as much as that of Parson's, is that sociology - whether conceived as oriented to internal research problems, matters of policy, or public debate-does not appear to demonstrate any strong tendency toward convergence on agreed concepts, methods, or accumulated knowledge. ${ }^{31}$

We seem to be between the horns of a dilemma-neither the attempt to "depoliticize" sociology nor its greater politicization is likely to produce the desired outcome of public legitimacy. However, I want to suggest that if the greater public legitimacy of sociology depends on at least some temporary convergences then this is more likely to be achieved by the realistic acceptance of the "politics of knowledge production" than by seeking to expunge "politics" or by its opposite, accelerated politicization. This does mean accepting Burawoy's call to recognize the public nature of sociology, but not in the foundational form in which he presents it.

Sociology may be less integrated and more ad hoc than natural science, but it does produce knowledge and engage in problem-solving activities in an analogous manner. Looser though integration may be, some degree of integration - that is, mutual engagement with problems and the attempt to resolve differences through argument and evidence - is necessary for problem solving to take place. However, I suggest that in sociology the "binding" that can generate mutual engagement is provided more by politics than by theoretical foundations or the theoretical assumptions of a research program. This binding is not a shared agreement on politics, but a shared concern

\footnotetext{
${ }^{30}$ I should stress that I am not arguing that sociology could not create a public, but against the generalization of this possibility as something that could provide the ultimate validation of sociology.

${ }^{31}$ Indeed, Buxton and Turner (1992) suggest that the development of professional sociology in the second phase was built on an earlier close relation between sociology and a reform public and progressivist politics. It is in part the declining impetus of that combination of "interests" that also undermined the professional project. However, in the current context of neoliberal and neoconservative politics that coalition has been undermined and, they suggest, is unlikely to return in the near future. See also Isaac (2003).
} 
with particular political issues. If the standard "professional" conception of publicly relevant social research independent of politics is flawed, then, this does not mean that social inquiry can be grounded in a political position, as Burawoy suggests. This would be a similar form of a priorism as that promoted in the name of general theory, albeit one where it is agreement on politics that precedes inquiry.

My conclusion, then, is that precisely because sociology is a contested field all sociologies - professional, no less than public - are in a critical relation with each other. The critical role cannot be assigned to one kind of sociology. However, because our field is contested, we have problems in carrying our knowledge into the public arena and having its claims accepted or its legitimacy unquestioned. I shall suggest that this does make sociology "dialogic" but it is a dialogue in which we should expect a public contestation of our claims, just as we contest the claims of each other. This does not undermine sociology as a professional practice. In contrast, I shall suggest that it constrains us to be rigorous in our practices, modest in our claims, and open to the surprise and pleasure of learning from others, including those we might construct as adversaries. We share spaces as sociologists, but we do not need to share assumptions. This suggests a revised understanding of professional "ethics." We are members of broadly based professional associations in which we can mutually benefit from our differences. Yet, how we conduct ourselves may well have consequences for others seeking to make their different contribution to the dialogues in which sociologists are engaged. Political neutrality is central to the corporate organization of sociology, not because it secures objectivity, nor because social inquiry can, or should be, value-neutral. ${ }^{32}$ It is central because it creates the space for dialogue and is the condition for any sociology to have a voice.

\section{REFERENCES}

Acker, J. 2005. "Comments on Burawoy on Public Sociology." Critical Sociology 31:327-31.

Agger, B. 2000. Public Sociology: From Social Facts to Literary Acts. Lanham: Rowman and Littlefield.

Alexander, J. C. 1982. Theoretical Logic in Sociology, Volume I, Positivism, Presuppositions and Current Controversies. London: Routledge and Kegan Paul. 1998. Neofunctionalism and After. Oxford: Blackwell.

American Sociological Association, n.d. Code of Ethics. Available at http://www.asanet.org/page.ww? section $=$ Ethics \&name $=$ Code \pm of \pm Ethics \pm Table \pm of \pm Contents

- Footnotes: Newsletter of the American Sociological Association.

Bauman, Z. 1987. Legislators and Interpreters: On Modernity, Postmodernity and Intellectuals. Cambridge: Polity.

Beck, U. 2005. "How Not to Become a Museum Piece." British Journal of Sociology 56:335-43.

Becker, M. 1994. The Emergence of Civil Society in the Eighteenth Century. Bloomington, IN: Indiana University Press.

Bell, D. 1960. The End of Ideology: On the Exhaustion of Political Ideas in the Fifties. New York: Free Press.

Bhambra, G. K. 2007. Rethinking Modernity: Postcolonialism and the Sociological Imagination. London: Palgrave.

Buroway, M. 2004. "Public Sociology: Contradictions, Dilemmas and Possibilities." Social Forces 82:160318.

2005. "For Public Sociology." American Sociological Review 70:2-28.

2005a. "The Return of the Repressed: Recovering the Public Face of US Sociology, One Hundred

Years on." Annals of the American Academy of Social and Political Science 600:68-85.

${ }^{32}$ For a defense of value neutrality in the context of Burawoy's address, see Nielsen (2005). 
Buxton, W. and S. P. Turner. 1992. "From Education to Expertise: Sociology as a "Profession." Pp. 373407 in Sociology and its Publics: The Forms and Fates of Disciplinary Organization, edited by T. C. Halliday and M. Janowitz. Chicago: University of Chicago Press.

Capell, C. L. and T. M. Guterbock. 1992. "Visible Colleges: The Social and Conceptual Structure of Sociology Specialities." American Sociological Review 57:266-73.

Colander, D. 2000. "The Death of Neoclassical Economics." Journal of the History of Economic Thought 22:127-43.

Coleman, J. A. 1990. The Foundations of Social Theory. Cambridge: Belknap Press.

Collini, S. 2006. Absent Minds: Intellectuals in Britain. Oxford: Oxford University Press.

Collins, R. 1990. "Market Closure and the Conflict Theory of the Professions." Pp. 24-43 in Professions in Theory and History, edited by M. Burrage and R. Torstendahl. London: Sage.

. 1994. "Why the Social Sciences Won’t Become High-Consensus, Rapid Discovery Science." Sociological Forum 9:155-77.

Connell, R. W. 1997. "Why is Classical Theory Classical?" American Journal of Sociology 102:1511-57. 2000. "Sociology and World Market Society." Contemporary Sociology 29:291-96.

Crane, D. and H. Small. 1992. "American Sociology Since the Seventies: The Emerging Identity Crisis in the Discipline." Pp. 197-234 in Sociology and Its Publics: The Forms and Fates of Disciplinary Organization, edited by T. C. Halliday and M. Janowitz. Chicago: University of Chicago Press.

D’Antonio, W. V. 1992. "Recruiting Sociologists in a Time of Changing Opportunities." Pp. 99-136 in Sociology and Its Publics: The Forms and Fates of Disciplinary Organization, edited by T.C. Halliday and M. Janowitz. Chicago: University of Chicago Press.

Davis, J. B. 2002. “The Emperor's Clothes.” Journal of the History of Economic Thought 24:141-54.

Durkheim, E. 1992. Professional Ethics and Civic Morals, translated by Co. Brookfield. London: Routledge.

Ennis, J. G. 1992. "The Social Organization of Sociological Knowledge: Modeling the Intersection of Specialities." American Sociological Review 57:259-65.

Fuller, S. 2000. "The Coming Biological Challenge to Social Theory and Practice." Pp. 174-90 in For Sociology: Legacies and Prospects, edited by J. Eldridge, J. MacInnes, S. Scott, C. Warhurst, and A. Witz. Durham, UK: Sociology Press.

Ghamara-Tabrizi, B. 2005. "Can Burawoy Make Everybody Happy? Comments on Public Sociology." Critical Sociology 31:361-69.

Gibbons, M., C. Limosges, H. Nowotny, S. Scwartzman, P. Scott, and M. Trow. 1994. The New Production of Knowledge. London: Sage.

Goldthorpe, J. H. 2000. On Sociology: Numbers, Narratives and the Integration of Research and Theory. Oxford: Oxford University Press.

Goodwin, C. D. 1998. "The Patrons of Economics in a Time of Transformation." Pp. 53-81 in From Interwar Pluralism to Postwar Neoclassicism, edited by M. Morgan and M. Rutherford. Durham, NC: Duke University Press.

Gouldner, A. W. 1970. The Coming Crisis of Western Sociology. London: Heineman. - 1973. For Sociology: Renewal and Critique in Sociology Today. London: Allen Lane. 1973a. "Anti-Minotaur: The Myth of a Value-Free Sociology." Pp. 3-26 in For Sociology: Renewal and Critique in Sociology Today. London: Allen Lane.

. 1973b. "Remembrance and Renewal in Sociology." Pp. 69-81 in For Sociology: Renewal and Critique in Sociology Today. London: Allen Lane.

Habermas, J. 1976. Legitimation Crisis, translated by T. McCarthy. London: Heineman. 1988. On the Logic of the Social Sciences, translated by Sh. W. Nicholson and J. A. Stark. Cambridge: Polity.

Hirschman, A. O. 1977. The Passsions and the Interests: Political Arguments for Capitalism Before Its Triumph. Princeton, NJ: Princeton University Press.

Hirshleifer, J. 1985. "The Expanding Domain of Economics." American Economic Review 75:53-68.

Horowitz, I. L. 1994. The Decomposition of Sociology. New York: Oxford University Press.

Isaac, J. C. 1999. "Is the Revival of Pragmatism Practical, or What Are the Consequences of Pragmatism?" Constellations 6:561-86. 2003. The Poverty of Progressivism: The Future of American Politics in a Time of Liberal Decline. Lanham: Rowman and Littlefield.

Jacoby, R. 1987. The Last Intellectuals: American Culture in the Age of Academe. New York: Noonday Press.

Karides, M., J. Misra, I. Kennelly, and S. Moller. 2001. "Representing the Discipline: Social Problems Compared to ASR and AJS." Social Problems 48:111-28. 
Ladd, E. C. and S. M. Lipset. 1975. The Divided Academy: Professors and Politics. New York: McGraw Hill.

Lakatos, I. 1970. "Falsification and the Methodology of Scientific Research programs." Pp. 91-196 in Criticism and the Growth of Knowledge, edited by I. Lakatos and A. Musgrave. Cambridge: Cambridge University Press.

Larson, M. S. 1977. The Rise of the Professions: A Sociological Analysis. Berkeley: University of California Press.

Leedham, C. S. and S. D. Eitzen. 1994. "Advocacy and the SSP: An Analysis of Research Articles in Social Problems." American Sociologist 25:66-73.

Mayer, T. 2001. "The Role of Ideology in Disagreements Among Economists: A Quantitative Analysis." Journal of Economic Methodology 8:253-73.

Mills, C. W. 1959. The Sociological Imagination. New York: Oxford University Press.

Moody, J. 2004. "The Structure of a Social Science Collaboration Network: Disciplinary Cohesion from 1963-1999." American Sociological Review 69:213-38.

Morgan, M. and M. Rutherford (eds). 1998. From Interwar Pluralism to Postwar Neoclassicism. Durham, NC: Duke University Press.

Mouzelis, N. 1995. Sociological Theory: What Went Wrong? Diagnoses and Remedies. London: Routledge.

Nielsen, F. 2005. "The Vacant 'We': Remarks on Public Sociology." Social Forces 82:1619-27.

Novotny, H., P. Scott, and M. Gibbons. 2001. Re-Thinking Science. Cambridge: Polity.

Parsons, T. 1954. "The Prospects of Sociological Theory." Pp. 348-69 in Essays in Sociological Theory. New York: Free Press.

1959. "Some Problems Confronting Sociology as a Profession." American Sociological Review 24:547-69.

- 1978. "The University 'Bundle': A Study of the Balance Between Differentiation and Integration." Pp. 133-53 in Action Theory and the Human Condition. New York: Free Press.

Parsons, T. and G. M. Platt in collaboration with N. J. Smelser. 1973. The American University. Cambridge: Harvard University Press.

Polanyi, K. 1944. The Great Transformation: The Political and Economic Origins of Our Time. Boston: Beacon Press.

Ricketts, M. and E. Shoesmith. 1992. "British Economic Opinion: Positive Science and Normative Judgement." American Economic Review 82:210-15.

Runciman, W. G. 1998. "The Selectionist Paradigm and Its Implications for Sociology." Sociology 32:16388.

Sayer, A. 2000. "For Postdisciplinary Studies: Sociology and the Curse of Disciplinary Parochialism and Imperialism." Pp. 83-92 in For Sociology: Legacies and Prospects, edited by J. Eldridge, J. MacInnes, S. Scott, C. Warhurst, and A. Witz. Durham: Sociology Press.

Scott, J. 2005. "Sociology and Its Others: Reflections on Disciplinary Specialization and Fragmentation." Sociological Research Online 101. Available at: http://www.socresonline.org.uk/10/1/scott.html.

Seidman, S. 1994. Contested Knowledge: Social Theory in the Postmodern Era. Oxford: Blackwell Publishers.

Silver, A. 1989. "Friendship and Trust as Moral Ideals: An Historical Approach." Archives Europenne de Sociologie XXX:274-97.

Simpson, I. H. and R. L. Simpson. 1994. "The Transformation of the American Sociological Association." Sociological Forum 9:259-78.

Slaughter, S. and G. Rhoades. 2004. Academic Capitalism and the New Economy. Baltimore: Johns Hopkins Press.

Smelser, N. J. and R. Swedberg (eds.). 1994. The Handbook of Economic Sociology. Princeton: Princeton UP.

Stacey, J. 2005. "Marital Suitors Court Social Science Spin-Sters: The Unwittingly Conservative Effects of Public Sociology." Social Problems 51:131-45.

Stanley, L. 2005. "A Child of Its Time: Hybridic Perspectives on Othering in Sociology." Sociological Research Online 103. Available at http://www.socresonline.org.uk/10/3/stanley.html.

Stinchcombe, A. L. 1994. "Disintegrated Disciplines and the Future of Sociology." Sociological Forum 9:279-91.

Taylor, P. J. 2000. "Embedded Statism and the Social Sciences 2: Geographies and Metageographies in Globalization." Environment and Planning A 32:1105-14.

Turner, J. A. and S. P. Turner. 1990. The Impossible Science: an Institutional Analysis of American Sociology. Newbury Park: Sage.

Turner, S. P. 2003. Liberal Democracy 3.0. London: Sage. 
Wallerstein, I., C. Juma, E. F. Keller, J. Kocka, D. Lecourt, V. Y. Mudkimbe, K. Miushakoji, I. Prigione, P. J. Taylor, and M.-R. Trouillot. 1996. Open the Social Sciences: Report of the Gulbenkian Commission on the Restructuring of the Social Sciences. Stanford: Stanford University Press.

Whitley, R. 2000. The Intellectual and Social Organization of the Sciences, 2nd ed. Oxford: Oxford University Press.

Winfield, R. D. 1988. The Just Economy. New York: Rutledge.

Wolfe, A. 1992. "Weak Sociology/Strong Sociologists: Consequences and Contradictions of a Field in Turmoil." Social Research 59:759-79.

Wright, E. O. 1985. Classes. London: Verso. 